
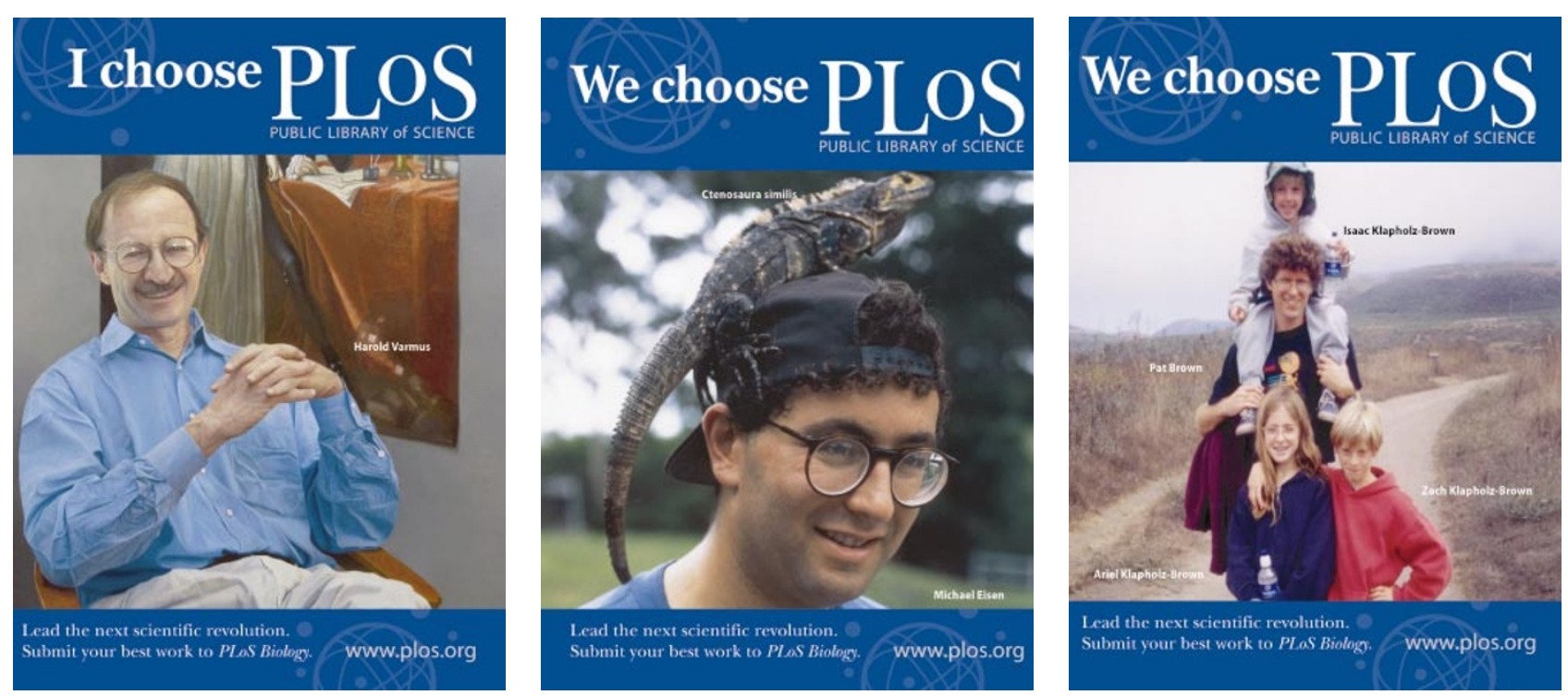

Campaign trail: the Public Library of Science's founders (above) have unleashed posters and a television advert (see stills below) to publicize their project.

\title{
Who will pay for open access?
}

\section{A new biology journal, positioned to compete with the likes of Nature, Science and Cell, aims to reinvent the economics of high-quality scientific publishing. Declan Butler examines the bottom line.}

n June and July, television viewers in three US cities were treated to a 30-second commercial, in which a besuited man emerged from his house, to the voiceover: "In the year 2003, the Public Library of Science made it possible for people all over the world to have access to the latest scientific discoveries. Shortly thereafter, things began to change." In a scene reminiscent of The Matrix: Reloaded, the man then zoomed off into the sky.

To the average viewer, it must have been perplexing stuff. The event being promoted was this month's launch of a journal called PLoS Biology, which aims to publish articles of "exceptional significance" in disciplines from molecular genetics to ecology. Published by a non-profit body called the Public Library of Science (PLoS), it is the spearhead of a campaign to provide open access to the scientific literature - making it free for anyone to read.

It's a compelling idea. Imagine, for instance, that you have just been diagnosed with a life-threatening illness, and want to find out about the latest advances in treatment. A search of the Medline literature database throws up hundreds of pertinent research papers. But unless you have subscriptions to the journals in question, or rack up your credit-card bill to download individual articles, many of the full texts will remain out of bounds - even though your taxes helped to pay for much of the research.

PLoS's aim is to show that open access can work by competing head-on for the best research papers with today's top scientific and medical journals, such as Nature, Science, Cell and The New England Journal of Medicine. PLoS Biology will be joined next year by $P L o S$ Medicine, and perhaps later by a series of discipline-specific publications.

Few people would disagree, in principle, with the ideal of open access. The question is whether the economics can be made to work. Employing peer review to sift through hun- dreds of manuscripts, and then editing the accepted ones into shape, can be an expensive business. Conventionally, publishers recoup these costs - and in the case of commercial publishers, make some of their profits - by charging for access to the final product. PLoS aims to turn this 'reader-pays' model on its head, instead charging a 'dissemination fee' to the authors of accepted papers. It believes that US $\$ 1,500$ per published article will do the job. In practice, the expectation is that this will be paid by universities or institutes, or by the agencies that fund researchers' work.

Behind the rhetoric of PLoS's campaign, therefore, lie some more down-to-earth questions. Will scientists, their host institutions, and those who fund their research embrace the 'author-pays' model? And if they do, is $\$ 1,500$ per article enough to cover the costs of producing a journal of the highest quality?

For most researchers in the physical sciences, PLoS's campaign is a side issue: they
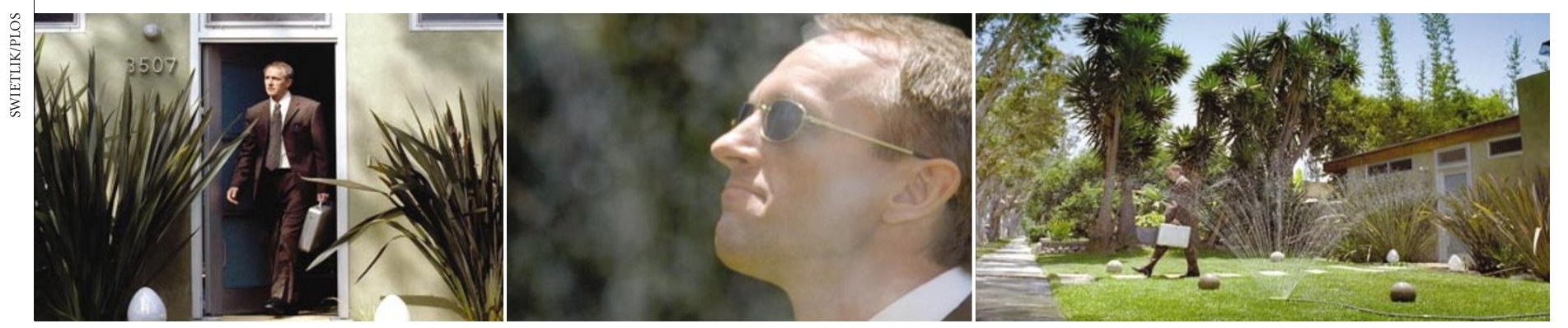
routinely make their papers freely available, before formal publication, using online preprint archives such as arXiv.org. But for biologists, who are not generally comfortable with prepublication, the answers to the questions thrown up by the launch of PLoS Biology may define the future of scientific communication. How things will pan out remains unclear. "We'll be watching with interest to see whether PLoS and others can make the economics work," says Annette Thomas, managing director of Nature Publishing Group.

PLoS began life in 2000, when a group of leading biologists circulated an open letter requesting that scientific publishers make the contents of their journals free for all to access online within six months of initial publication. PLoS's founders included Nobel laureate Harold Varmus, president of the Memorial Sloan-Kettering Cancer Center in New York, DNA-microarray pioneer Patrick Brown of Stanford University in California, and computational and evolutionary biologist Michael Eisen of the Lawrence Berkeley National Laboratory, also in California. Their letter attracted more than 30,000 signatures - although few signatories seem to have followed through on their pledge to stop submitting to and reviewing for journals that have not acceded to PLoS's call for open access. These journals remain in the majority - hence PLoS's decision to launch its own publishing enterprise.

\section{Mixed strategy}

PLoS is not alone in exploring the possibilities of open-access publishing. Several scientific publishers, such as Oxford University Press and Britain's Institute of Physics, are experimenting with open access. Some journals, such as the American Physiological Society's Physiological Genomics, are allowing authors to pay for open online access for individual papers, while retaining a subscription model for the journal as a whole. And 1999 saw the launch of the Londonbased BioMed Central (BMC), which today boasts a roster of almost 150 online openaccess journals, most of which have now published their first handful of papers.

In its pure, open-access form, PLoS Biology will also be an online product - a print version will be available for $\$ 160$ per year. But PLoS differs from BMC in its lofty editorial ambitions. It has pitched itself at the élite end of the market, competing with journals that

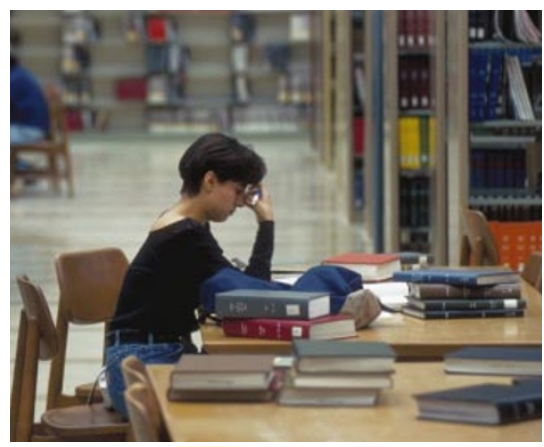

Universities may be reluctant to fund open-access papers while still paying for library subscriptions.

aim to publish only the best or most significant research. This can mean rejecting more than $90 \%$ of submitted manuscripts, which in turn means that editorial costs per published paper are very high — much higher than $\$ 1,500$, say some experts.

Many publishers decline to reveal details of their costs. But most have examined the issue and find PLoS's estimate hard to understand. Publishing primarily online should reduce production costs by around $20 \%$, compared with a journal with a large print run. But that still leaves considerable costs for staffing and administration. "I feel that PLoS's estimate is low by four- to sixfold," says cell biologist Ira Mellman of Yale University, editor of the The Journal of Cell Biology, published by Rockefeller University Press. He notes that PLoS has hired six full-time editors - some former employees of Nature or Cell - and is based in San Francisco, an extremely expensive city.

PLoS's supporters reject such arguments, pointing out that they come from journals with a vested interest in the reader-pays status quo. Eisen says that the $\$ 1,500$ figure is based on a 100-page business plan thrashed out with publishing experts. "PLoS needs to break even in just a few years, so we have every incentive to get the number right," he says.

In the first instance, PLoS will be cushioned by a grant from the San Francisco-based Gordon and Betty Moore Foundation. If PLoS meets publishing targets agreed with the foundation - which have not been made public this grant will total $\$ 9$ million over five years.

But in the longer term, PLoS and other open-access groups must persuade the organizations and institutions that fund and host biology research to pay their fees. Grants from the US National Institutes of Health already allow for the charging of publication fees. Other bodies are moving in the same direction. The Howard Hughes Medical Institute, for example, has agreed to provide its investigators with up to $\$ 3,000$ each in 2004 to cover open-access fees. On 1 October, Britain's Wellcome Trust announced that it, too, is prepared to meet the costs of open-access publishing (see Nature 425, 440; 2003). And Germany's main research agencies are expected to make a similar announcement later this month.

\section{Transition time}

PLoS and other open-access groups are now waiting for word from the bulk of universities and research institutes around the world. "We are in a transitional period," says Peter Suber of the advocacy group Public Knowledge, based in Washington DC. He notes that many institutions will be reluctant to cover dissemination fees while still paying subscriptions to traditional journals.

Before these issues are resolved, however, PLoS Biology will have to overcome the hurdle that faces any new journal, irrespective of its business model: convincing scientists, particularly young researchers who need to publish in high-profile journals to further their careers, that it is worth taking the risk on a new and unknown quantity. "We are off to a very fast start, with submissions steadily increasing even before we've launched," claims Eisen.

Most publishers remain sceptical about the viability of PLoS's eventual goal of converting the entire scientific literature to the open-access model. But many now accept that the author-pays approach may have its place. In August, the Association of Learned and Professional Society Publishers declared itself "wholly in favour of maximizing access to research literature; the various proposals for achieving this ... raise complex economic, logistical and sociological questions which differ from field to field as well as between different sizes and types of publishers. Much more information needs to be gathered through experimentation and analysis."

With the launch of PLoS Biology, a key experiment is now up and running. Declan Butler is Nature's European correspondent. Public Library of Science

\section{www.plos.org}

BioMed Central

www.biomedcentral.com
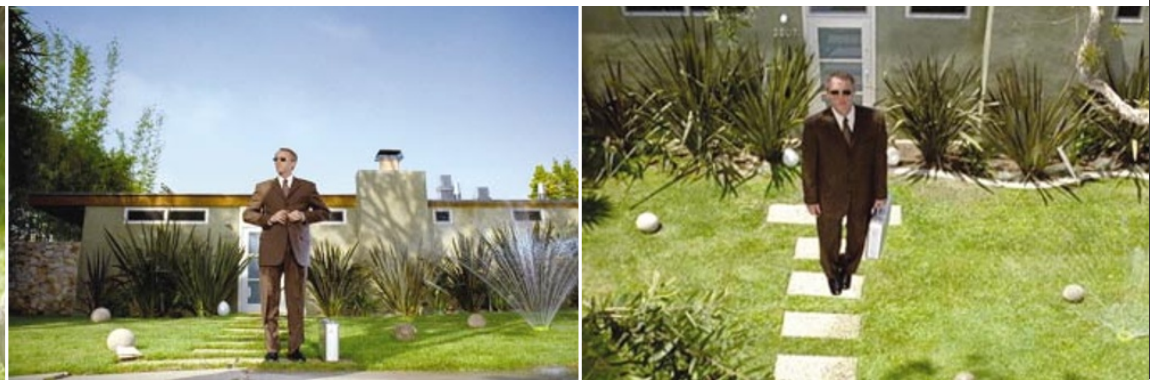